\title{
Review
}

\section{Gypsum resources of Spain: Temporal and spatial distribution}

\author{
J.I. Escavy *, M.J. Herrero, M.E. Arribas \\ Dpto. de Petrologín y Geoquímica, Faultad de Ciencias Geológicas, Universidad Complutense de Madrid, C/ José Antonio Novais, 2, 28040 Madrid, Spain
}

Keywords:

Gypsum resources

GIS

Surface evaluation

Depositional factors

\begin{abstract}
A B S T R A C T
Spain is one of the main gypsum producers in the world. Spanish gypsum reserves are large and a good knowledge of the location of the ore reserves permits to establish better exploitation strategies. Plotting the Spanish major gypsum outcrops, using a GIS base, helps to classify them by age, establish the main depositional character and determine the factors controlling their origin.

Evaporitic deposits from Cambrian to Quaternary are preserved throughout Spain. The evaporites are formed by chemical precipitation of natural brines, either of marine or continental origin. The oldest evaporite vestiges in the Spanish geological record have been described in carbonate materials, as gypsum and anhydrite pseudomorphs, in Cambrian deposits of the Cantabro-Iberian basin (northern Spain). The first properly identified evaporite formation in Spain is located in the Triassic deposits that characterize central and northern Europe. In Spain, evaporites of this age appear well represented in $4394.5 \mathrm{~km}^{2}$ of outcrop area in the eastern part of the Iberian Peninsula. The Iower Jurassic (covering $1068 \mathrm{~km}^{2}$ of outcrop area) and the Cretaceous (covering $706.9 \mathrm{~km}^{2}$ of outcrop area) are periods of intense evaporitic sedimentation, and outcrops appear concentrated towards central and eastern parts of the Peninsula. More recently, in the Cenozoic, numerous continental and marine basins resulted from the tectonic activity produced by the Alpine Orogeny. Here, a combination of different factors produced thick and wide evaporite accumulations (outcrop surface is $13592.7 \mathrm{~km}^{2}$ ). In the Quaternary, evaporitic conditions are common in Spain, including various saline lakes (covering $1092.1 \mathrm{~km}^{2}$ of outcrop area) mainly in the Ebro basin and La Mancha zone. In addition, there are many artificial marine salinas.

The evaporitic conditions in a basin strongly depend on factors such as climate, tectonics and brine composition. A study of the spatial distribution and age of the gypsum-bearing units in Spain suggests a wide variation in factors controlling the origin of gypsum deposits. The Spanish evaporite precipitation from Permian to Jurassic times was controlled by global conditions such as climate. They were formed during a global warming period. On the other hand, evaporites formed from late Cretaceous to Neogene were more influenced by regional factors that were related to the tectonic activity produced by the Alpine Orogeny. At present evaporite precipitation occurs due to the endorheic character of lakes in some parts of Spain.
\end{abstract}

\section{Contents}

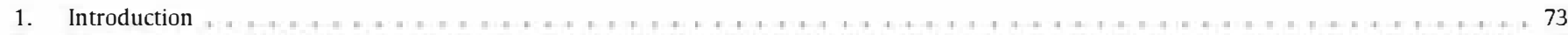

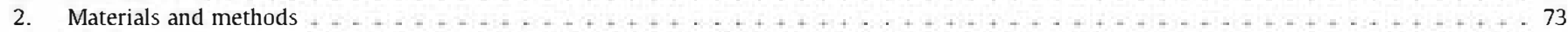

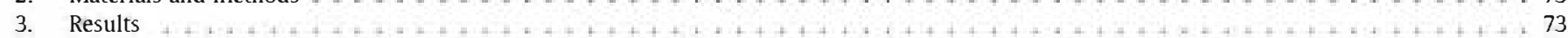

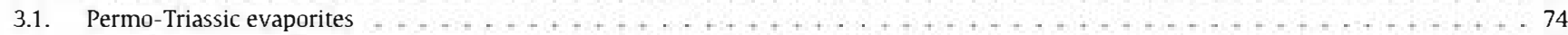

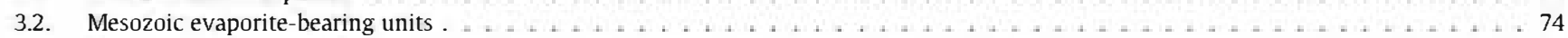

3.2.1. Triassic . . . . . . . . . . . . . . . . . . . . . . . . . . . . . . . . . . 75

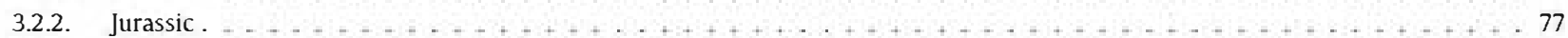

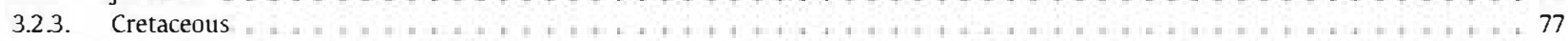

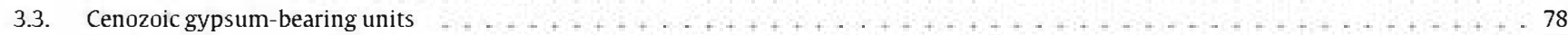

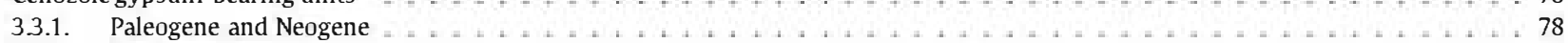

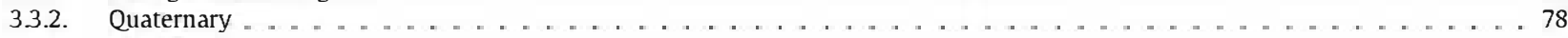

\footnotetext{
* Corresponding author. Tel.: + 34913944906; fax: + 34915442535.

E-mail addresses: jiescavy@geo.ucm.es (J.I. Escavy), mjherrer@pdi.ucm.es (M.J. Herrero), earribas@geo.ucm.es (M.E. Arribas).
} 
4. Discussion

4.1. Controls on evaporitic deposition in the geological record of Spain $\ldots \ldots \ldots \ldots \ldots \ldots \ldots$

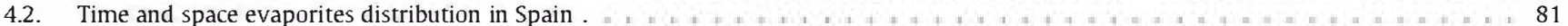

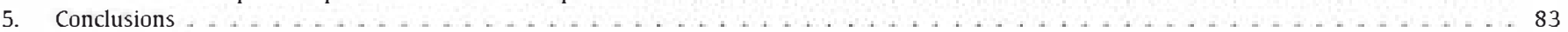

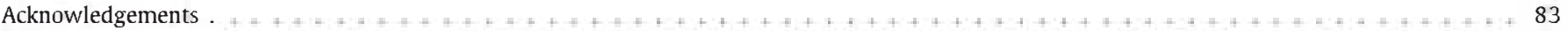

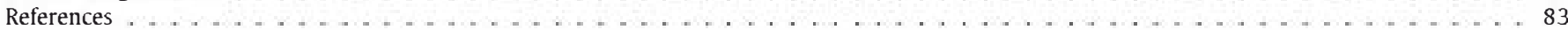

\section{Introduction}

Gypsum is one of the most common evaporitic mineral in the geological record and the most frequent in outcrop due to its lower solubility compared with other evaporites such as halite, glauberite, etc. Even though halite is the main precipitation phase from the sea water, it is rapidly altered and, therefore, it is poorly or not preserved in outcrop (Schreiber and El Tabakh, 2000).

Gypsum was the seventh largest natural mineral commodity mined in the world in 2009 after aggregates, iron ore, lime, salt, bauxite and phosphate rocks (Salazar and McNutt, 2011). According to these authors, world production of gypsum for that year was estimated at 148 million tonnes. Spain, with a production of 11.5 million tonnes, was the leading European producer and ranked third in the world, after China and Iran. Spanish gypsum production was obtained from 118 quarries and most of the production was exported mainly to UK, Nigeria, Venezuela and the United States (Escavy et al., 2011). All gypsum mined in Spain is by opencast methods, therefore, a better understanding of the character, quality, quantity and location of gypsum outcrops would permit to establish future mining development strategies.

The main objective of our work is to establish a detailed surface quantification of the different gypsum-bearing units present in the geological record of the Iberian Peninsula, where gypsum is one of the major outcropping industrial minerals. Riba and Macau (1962) have previously analyzed the Spanish gypsum occurrences and their geographical distribution. This study has been extensively used and their results of surface calculations are still cited in various works (Alberto and Navas, 1986; Gutiérrez et al., 2008; Laya et al., 1993; Porta et al., 2003; Sanz, 2009). The currently available digital technologies, such as Geographic Information Systems (GIS), allow integrating and analyzing an enormous amount of geographical and geological information. In addition, public databases offered by different institutions, provide the basic information such as topography, geology, urban areas, infrastructures and protected areas to be used by GIS software. In this study, the analysis and evaluation of the outcrops of evaporite-bearing geological units have been accomplished using ArcGISe. The main raw data was obtained from digital and paper collection of the Spanish Geological Map, scale 1:50000.

\section{Materials and methods}

Pursuing the principal objective of this work, we have applied a methodology that allowed us to integrate, compare and update previous works (Riba and Macau, 1962). In addition, this study adds new qualitative and quantitative data on evaporite outcrops and their distribution in Spain. One of the most used GIS software in mineral resources exploration is ArcGISe, being a standard for most of this type of study. We have done this work with ArcMap 10.0 and ArcCatalog 10.0 modules of the ArcGIS software. The raw data used for this study is based on the Spanish National Geological Map (MAGNA), scale 1:50000, published by the Spanish Geological Survey ("Instituto Geológico y Minero de España - IGME"). This cartographical series divides Spain into 1065 geological sheets. A total of 1048 geological sheets have been analyzed for this study, whereas 17 unpublished sheets have not been used. The Canary Islands are not included in this work because of the lack of geological gypsumbearing units at the work scale of this study (1:50000).

About $86 \%$ of the geology of Spain has been already incorporated into GEODE, which is an IGME's working plan that transforms the individual geological sheets of the 1:50000 scale MAGNA's geological cartography into a continuous geological map. This freely accessible information is the main material used for this study (IGME, 2012). The downloaded material is in vector format, with a GCS_European_1950 geographic coordinate reference, and ED_1950_UTM Zone_29N, Zone $30 \mathrm{~N}$ and Zone $31 \mathrm{~N}$ projections. The geological data are grouped into 28 regions, called GEODE Zones (Fig. 1), corresponding approximately to the main geological domains.

In our study, individual sheets of the same GEODE Zone have been merged together. In each GEODE Zone, the geological units that contain evaporitic materials are selected and extracted as individual ArcGIS $^{\bullet}$ features. From this analysis, a total of 201 geological units containing evaporites have been obtained. In order to simplify and accelerate further calculations, all the evaporite polygons for each geological unit and each GEODE Zone have been merged to get one single feature.

The evaporitic units present in the original printed format have been analyzed in places where GEODE is not complete, which is about $14 \%$ of Spain's surface. For all missing sheets where evaporites are present, they have been digitized with ArcGISe software. The base geological maps for digitizing the features have been downloaded from the IGME's site in a georeferenced raster format.

\section{Results}

A database has been created integrating the data obtained by merging the evaporite-bearing units from different time periods of the geological record in the Iberian Peninsula. From the GIS data processing, the total area of Spain occupied by gypsiferous materials is $4.2 \%$. This result has been obtained by the areal measurement of all the gypsum-bearing outcrops, and is significantly different to the $7.2 \%$ obtained previously by Riba and Macau (1962). This is mainly due to the fact that more detailed mapping information is currently available, with additional information produced in the last 50 years by many authors, using more accurate constrain in ages and characterization of the different gypsum-bearing geological units.

To accurately evaluate the gypsum resources it would be necessary to take into account the vertical thicknesses of the deposits. From a mining perspective, Regueiro and Calvo (1997) estimated the possible resources of gypsum in Spain as 60000 million tonnes (based on the IGME's National Plan of Gypsum Exploration, 1968-1989). These resources are vast compared with the average Spanish production of 11 million tonnes per year during the time period 2000-2011.

Due to diagenetic and post-depositional transformations, gypsum is the principal evaporite mineral outcropping in all geologic time intervals, with few anhydrite and halite occurrences such as those of Cardona Salt Mountain (Paleogene, Ebro basin), and De la Rosa and Pinoso diapirs (Triassic, Prebetic Zone). The total outcrop area of evaporite units in Spain is $21077.1 \mathrm{~km}^{2}$ (Table 1). This surface represents $4.2 \%$ of the total area of the country, and it is concentrated in the central and eastern parts of the territory (Fig. 2). About 1\% of the gypsiferous area corresponds to Permo-Triassic materials, $29.3 \%$ to 


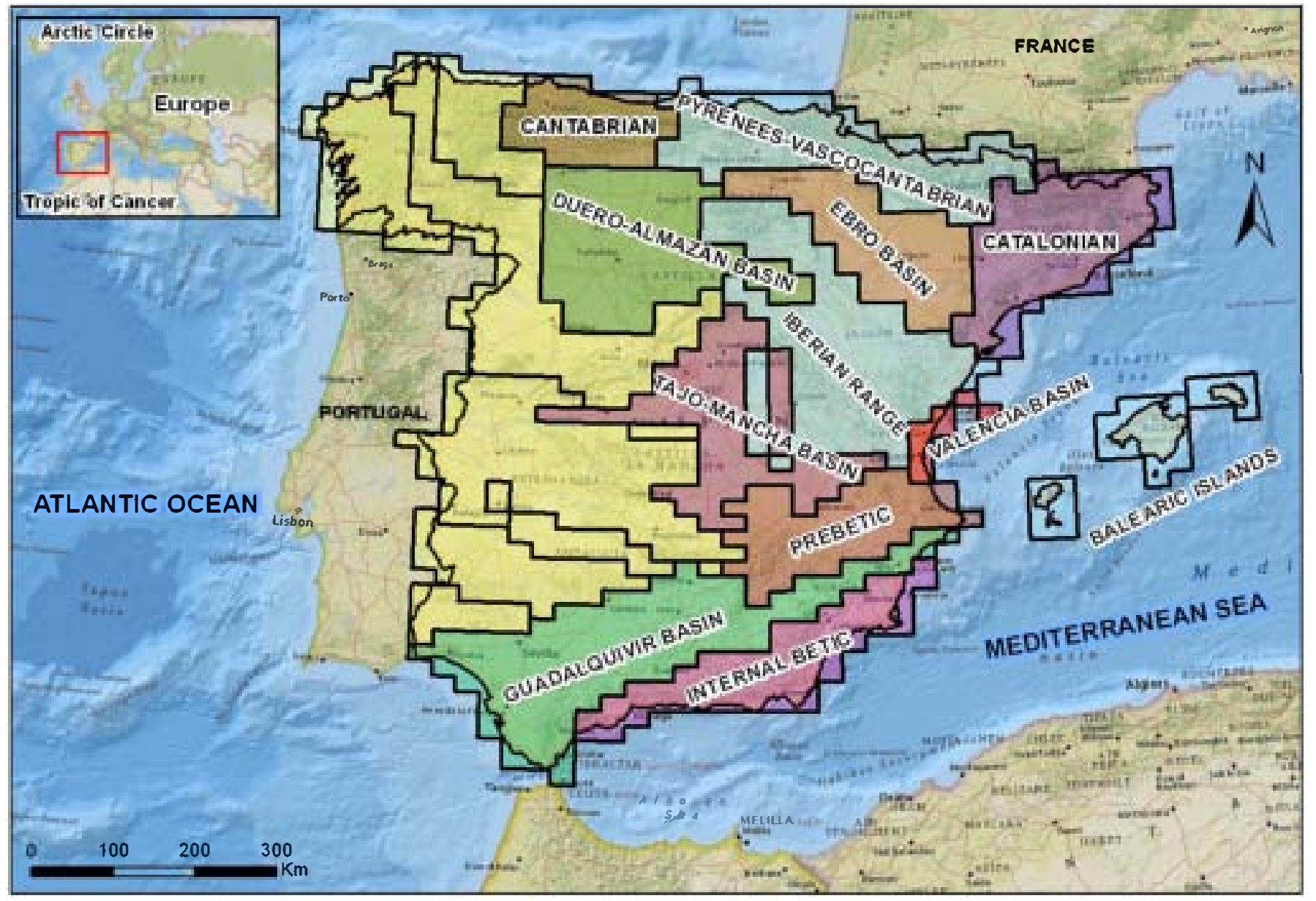

Fig. 1. Distribution of the GEODEZones in Spain (IGME, 2012). Labels appear only on the Zones containing evaporites-bearing units.

Mesozoic units, mainly Upper Triassic deposits, and 69.7\% to Cenozoic materials, most of them of Neogene age (Table 1).

First evidence of evaporite sedimentation in the geological history of Spain appears in lower Cambrian rocks, where evaporitic conditions were highlighted by Álvaro et al. (2000) in the Jalón, Ribota and Huérmeda Formations of the Cantabro-Iberian basin. In these sequences, evaporitic conditions are interpreted based on the appearance of evaporitic mineral pseudomorphs that have been replaced by quartz and dolomite.

Table 1

Outcrop area of the gypsum-bearing units in $\mathrm{km}^{2}$ classified by age.

\begin{tabular}{lll}
\hline & Outcrop area $\left(\mathrm{km}^{2}\right)$ & $\%$ \\
\hline $\begin{array}{l}\text { Permo-Triassic } \\
\text { Mesozoic }\end{array}$ & 213.1 & 1.0 \\
Middle Triassic & 197.2 & \\
Upper Triassic & 4197.3 & \\
Jurassic & 1068.0 & \\
$\quad$ Cretaceous & 706.9 & $\mathbf{2 9 . 3}$ \\
Total Mesozoic & $\mathbf{6 1 6 9 . 3}$ & \\
Cenozoic & & \\
Paleogene & 2208.1 & \\
Neogene & 11384.6 & \\
$\quad$ Quaternary & 1092.1 & $\mathbf{6 9 . 7}$ \\
Total Cenozoic & $\mathbf{1 4 6 8 4 . 9}$ & $\mathbf{0 . 0}$ \\
Age not stated & $\mathbf{9 . 8}$ & $\mathbf{1 0 0 . 0}$ \\
Total & $\mathbf{2 1 0 7 7 . 1}$ & \\
\hline
\end{tabular}

\subsection{Permo-Triassic evaporites}

In the early Permian of the Sierra de Aragoncillo (Iberian Range), a dolomicrite with pseudomorphs of gypsum, anhydrite and halite appear in the upper part of the Autunian sequence (Marfil et al., 1984) reflecting evaporitic conditions at that time. Nevertheless, no evaporite deposits are found.

In the Internal Betic Zone there are gypsum-bearing Permo-Triassic rock types, occupying $213.1 \mathrm{~km}^{2}$ in the provinces of Almeria, Murcia and Malaga (Fig. 2, Table 1). These rock types have been described as irregular and tectonized gypsum masses with a chaotic structure (Aldaya et al., 1979; Egeler et al., 1974; Espinosa et al., 1974a; Espinosa et al., 1974b). Calcium sulfate appears well crystallized and occurs both as gypsum and anhydrite. No other evaporitic minerals have been described in these units. The gypsum occurs associated with shale and subvolcanic bodies in the Conglomeratic Marble Unit, on top of the Nevadofilábride nappe Complex. The age of this sequence is controversial, due to the fact that recent studies date the intercalated subvolcanic bodies as Paleocene-Eocene in age (Puga et al., 1996). Thickness is very variable and can attain several tens of meters. Iateral extension from western Sierra Nevada to Cartagena exceeds $250 \mathrm{~km}$.

\subsection{Mesozoic evaporite-bearing units}

Mesozoic gypsum outcrops cover a total surface of $6169.3 \mathrm{~km}^{2}$, representing $29.3 \%$ of the total Spanish gypsiferous territory. About $71.2 \%$ is Triassic in age, mostly Upper Triassic (Keuper facies), 17.3\% is Jurassic in age and $11.5 \%$ are Cretaceous rocks (Table 1 ). 


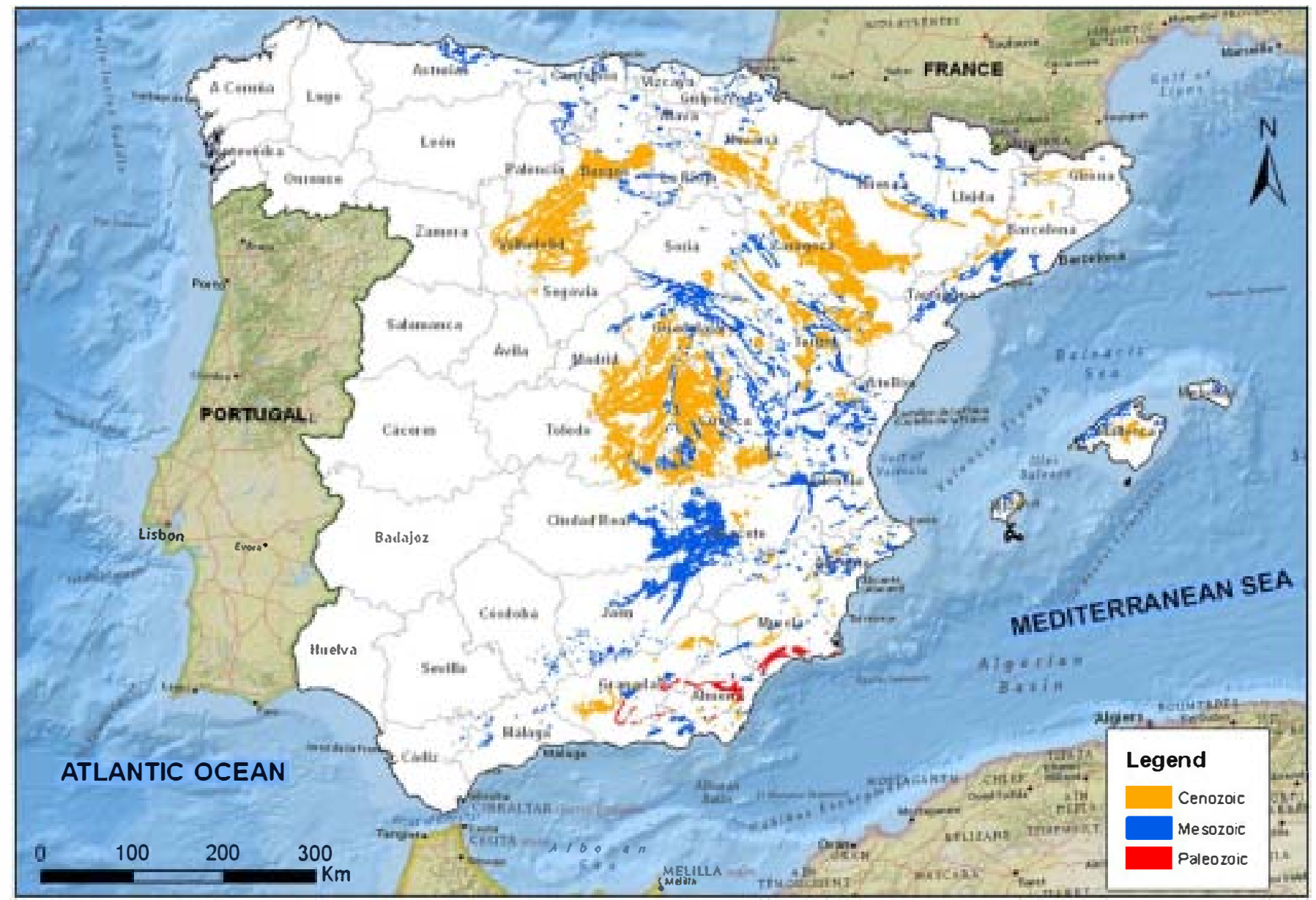

Fig. 2. Iocation of gypsum-bearing units outcrops in Spain classified by age.

\subsubsection{Triassic}

Triassic evaporites are the most abundant in the Spanish subsurface and rank second in terms of outcrop surface, after Neogene evaporites (Table 1). They have played a key role in the tectonic evolution during Alpine Orogeny, outcropping in all the Mesozoic mountain belts. All Triassic evaporites are marine in origin, according to the bromine content of the halite and the anhydrite isotopic composition $\left(\delta^{18} \mathrm{O}, \delta^{34} \mathrm{~S}\right.$ ) (Orti et al., 1996).

3.2.1.1. Lower Triassic (Buntsandstein facies). The first relevant report of Mesozoic evaporites occurrence in Spain is the uppermost part of the Buntsandstein facies of the Catalonian Coastal Range (Virgili, 1958). Calcium sulfate occurs both as gypsum and anhydrite in centimeter thick units interbedded with red marls and scarce thin limestone layers (Bartrina and Hernández, 1990; Ortí et al., 1996). In the Aragonese branch of the Iberian Range, Arribas (1986a) described the Trasobares Clays and Marls Unit, at the top of the Buntsandstein, as centimeter thick layers of secondary gypsum interbedded with clays. Sandstone bodies are heavily cemented by gypsum. They have been primarily deposited in ponds of an intertidal and supratidal coastal zone with arid climate conditions. Due to the abundance of interbedded waste materials, this unit lacks any economic interest.

3.2.1.2. Middle Triassic (Muschelkalk facies). In the geology of Spain, the complete Middle Triassic sequence is composed of two carbonate units of Anisian-Ladinian ages (M1 and M3) separated by a mudstoneevaporite bed (Detrital-Evaporitic Intercalation named M2) and represents two transgressive-regressive cycles. These sequences appear complete in the eastem part of the country but the lower units disappear progressively westwards (López-Gómez et al., 2002).

Muschelkalk evaporite facies appear in various GEODE Zones disributed in Cantabrian, Iberian Range, Prebetic, Intemal Betic, Valencia Subsiding basin and Catalonia (Figs. 1 and 3). These materials occur in the Detrital-Evaporitic Intercalation of the Germanic Trias, defined by Garrido-Megías and Villena (1977), and is the equivalent level to the Intermediate Red Layer (M2) of the Catalonian Coastal Ranges (Virgili, 1955) and the Dolostones and Upper Marls Unit of the Aragonese branch of the Iberian Range (Arribas, 1986a). The mineralogy of Middle Triassic evaporites is dominated by gypsum and anhydrite. These sulfate-rich rocks have undergone lateral facies changes into haliterich sediments formed in zones of higher subsidence rates. Halite in Middle Triassic reaches its maximum thickness in the Maestrat basin, where sodium chloride attains thicknesses of several hundred meters. The total surface area of these outcrops is around $197.2 \mathrm{~km}^{2}$ (Table 1).

3.2.1.2.1. Cantabrian Zone. In this GEODE Zone the occurrence of evaporite deposits of Middle Triassic is included in the Fuentes Formation (Gervilla et al., 1973), although more recently, palynological analyses dated this materials as Upper Triassic (Martinez-Garcia et al., 1998). These authors describe this unit as a succession of $200 \mathrm{~m}$ of red to greenish marls and silts interbedded with thin layers of sandstone. It is overlain by a $60 \mathrm{~m}$ thick unit of black and red marls, dolomites and gypsum. Rocks found in this area by Garcia-Mondejar et al. (1986) were limited to those with mouldic porosity and breccias formed by evaporites dissolution in the Muschelkalk facies. Robles and Pujalte (2004) defined the Muschelkalk facies of the Cantabrian Chain as composed of two carbonate units, a lower partially dolomitized and a 


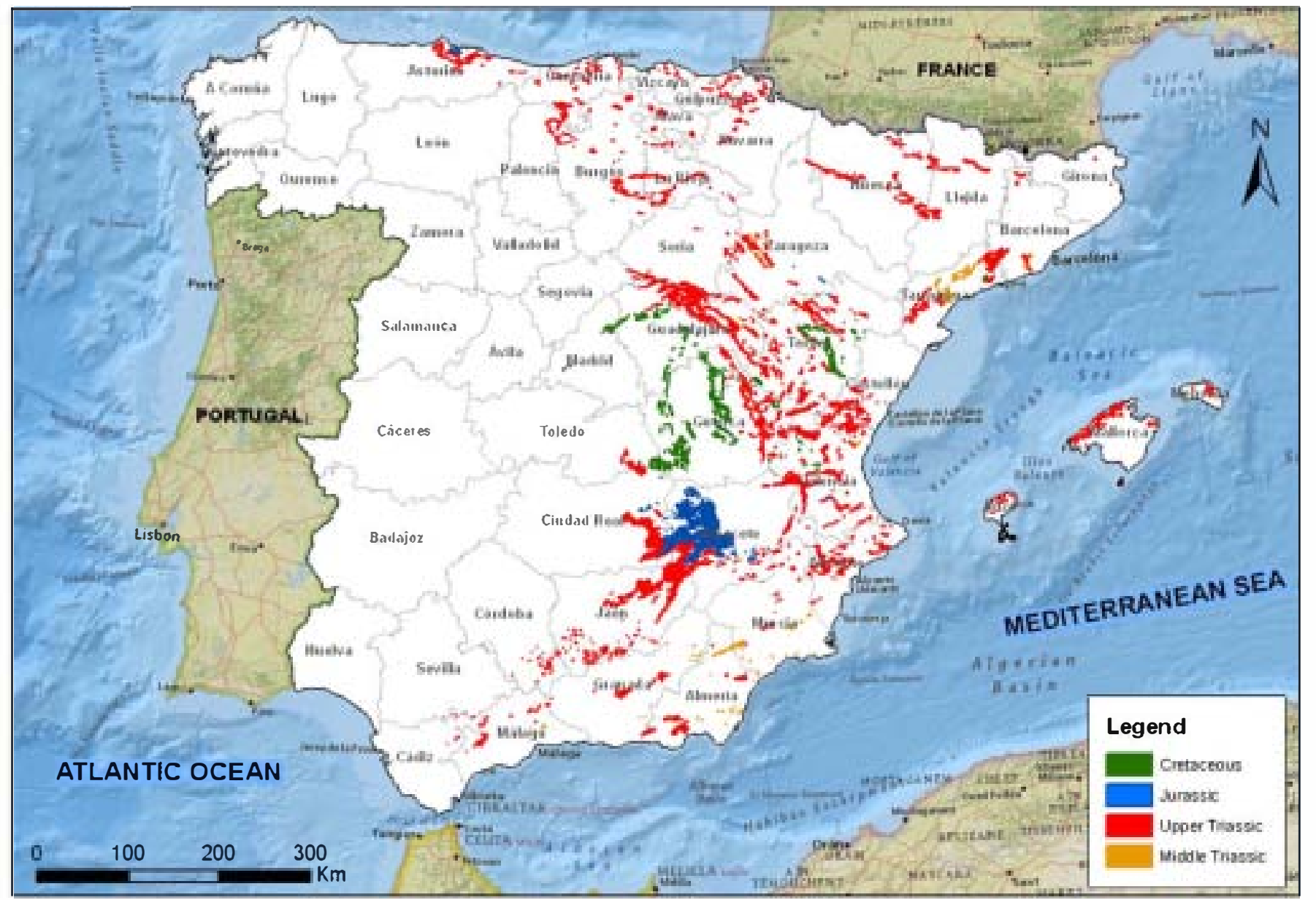

Fig. 3. Location of Mesozoic evaporite-bearing units outcrops.

completely dolomitized upper one. Towards the eastern GEODE Zones, the two carbonate units appear separated by the M2 (Garrido-Megias and Villena, 1977). Although GEODE evaporitic units are described for this age in the Cantabrian Zone, there is no clear evidence of their existence and these materials are not taken into account for further calculations.

3.2.1.2.2. Iberian Range Zone. This zone is divided into the northern or Aragonese branch, and the Meridional or Castilian branch, separated by the Cenozoic Calatayud and Teruel basins. In the Castilian branch, the three Middle Triassic members (M1, M2 and M3) appear complete in well-logs descriptions (López-Gómez et al., 2002) but the Detrital-Evaporitic Intercalation (M2) outcrops are not representative because these materials have acted as detachment levels and, in addition, evaporites have been dissolved at the surface. In outcrop, pseudomorphs of halite up to $3 \mathrm{~cm}$ width are found. These salts crystallized in the sediments of an inter-supratidal coastal zone (Ramos, 1979). In the Aragonese branch there is abundant mouldic porosity (Fig. 4A) and scattered carbonate and siliceous pseudomorphs after evaporitic minerals in the M2, some with anhydrite inclusions. This sequence is named the Dolostones and Upper Marls Unit (Arribas, 1986a), and the evaporites precipitated in supratidal sediments with indications of long periods of subaerial exposure.

3.2.1.2.3. Catalonian Zone. The Catalonian Coastal Range is the area where the Muschelkalk's Detrital-Evaporitic Intercalation (M2) outcrops have the wider lateral continuity (Virgili, 1958). These deposits range in thickness from 45 to $105 \mathrm{~m}$ and are composed of red clays and marls with gypsum, anhydrite, halite and minor carbonate layers. Gypsum and anhydrite are the most significant evaporitic components found in these lithologic units (Morad et al., 1995; Salvany, 1990).
3.2.1.2.4. Betic Zones. It is subdivided into the Internal and External Zones. The External Zone is included in the Guadalquivir Basin GEODE Zone and there are a few outcrops containing red and grey mudstones with thin layers of gypsum, assigned either to the upper part of the Buntsandstein or to the M2 (López-Gómez et al., 2002). Middle Triassic sequences of the Internal Zones are mainly carbonate with some non evaporitic units.

3.2.1.3. Upper Triassic (Keuper facies). The total Keuper facies surface in Spain is approximately $4197.3 \mathrm{~km}^{2}$ (Table 1). In the Iberian Range and the Prebetic GEODE Zones, the Keuper deposits represent almost $70 \%$ of the total Iberian Keuper outcrops. The remaining 30\% is broadly distributed throughout the Spanish territory (Catalonia, Pyrenees-Vascocantabrian Range, Internal Betic Zones, Valencia, Guadalquivir, and Tajo-Mancha Basins and the Balearic Islands) (Fig. 3).

3.2.1.3.1. Iberian Range Zone. In the Castilian branch this unit has been described as a succession of mudstones, marls and gypsum (Fig. 4B), with highly variable thickness due to changes produced by deformations related to the Alpine tectonic phase (López-Gómez et al., 2002). Authigenic quartz and aragonites (Fig. 4C) with anhydrite relicts are very common in these facies (Marfil, 1970). Evaporites occur as macrocrystalline gypsum crystals scattered or forming at various levels in the Los Gavilanes Clays and Gypsum Unit (Sopeña, 1979). In the Aragonese branch, Keuper deposits are widespread, with very poor quality outcrops. Del Olmo et al. (1983) described this unit as red, green and gray clays with nodules of secondary gypsum. According to those authors, these deposits were formed in a coastal flat, where successive sea transgression-regression cycles led to precipitation of evaporites in ephemeral lakes. 
al., 1979). These gypsum crystals have formed due to oxidative weathering of preexisting pyrite (Rodríguez-López et al., 2012) but the quantities formed have not been sufficient to be of economic interest.

3.2.3.2. Tajo-Mancha Basin Zone. this is a thick evaporite unit overlying the last carbonate marine platforms and underlying the Paleogene Unit (Arribas, 1986b) in the north-east of the Tajo basin. Here, the sequence is composed of white, black and reddish massive to fibrous gypsum interbedded with marls and clays (Adell et al., 1981). The lack of fossil remains in this unit makes it difficult to carry out precise age dating, but it may be considered late Cretaceous-early Paleogene in age. In the Cogolludo area, late Cretaceous-early Paleogene rocks attain thicknesses ranging between 800 and $1200 \mathrm{~m}$ (Portero et al., 1990). Gypsum beds are up to $90 \mathrm{~m}$ thick, with laminar, nodular and massive facies that represent a playa-lake environment. Such a playa-lake environment persisted in this area until Paleogene times. This gypsum is being extracted from a number of quarries mainly for plaster manufacture. In the La Mancha area, mouldic porosity of evaporites is found in dolomicrites of the Cenomanian, formed originally in an intertidal marine setting (Fernández-Calvo, 1981). This author also described mixed evaporitic-carbonate sedimentation in the Senonian, characterized by pseoudmorphs of evaporitic minerals. Associated intense brecciation is also found, interpreted as the result of the dissolution of evaporite layers.

3.2.3.3. Catalonian Zone. evaporites in this zone, mainly gypsum, are Albian in age. They appear related to sand, red clays and lignites. The main outcrop is located in Tarragona province, where scarce red gypsum and lignite layers are interbedded within yellow-brown marls and clays (Benzaquen et al., 1973).

3.2.3.4. Prebetic Zone evaporites are limited to the Rambla de los Gavilanes and Cerrillares Formations, where sedimentation occurred in Campanian and Maastrichtian coastal lakes and tidal flats (Vera et al., 2002). However, there is no mention of evaporite deposits in the literature reviewed for these two units (Arias et al., 1981; García-Velez and Soubrier, 1981; Garcia-Vélez et al., 1981; MartínChivelet, 1994). Therefore, these lithologic units are not taken into account for calculations.

\subsection{Cenozoic gypsum-bearing units}

\subsubsection{Paleogene and Neogene}

Sediments have been accumulated in several Paleogene and Neogene basins during and after the Alpine Orogeny in Spain. Most of these basins have undergone periods of intense evaporation during these Epochs, with the exception of the Guadalquivir basin, which was connected to the Atlantic Ocean during most of this period (Fig. 5).

3.3.1.1. Iberian Range Zone. sedimentation of evaporites during the Cenozoic in the GEODE Zone corresponds mainly to the Calatayud and Teruel basins (Fig. 5). These basins separate the Aragonian and Castilian branches of the Iberian Range. Both of them were formed by extensional tectonics during Miocene, and were filled with up to $1500 \mathrm{~m}$ of detrital alluvial fan deposits that change distally into palustrine and lacustrine deposits (Anadón et al., 1997; Orti and Rosell, 2000). Evaporites occupy the central areas of these systems.

3.3.1.2. Tajo-Mancha Basin Zone. Paleogene and Neogene evaporitic units of this Zone outcrop extensively (more than $4700 \mathrm{~km}^{2}$ ). This basin is divided in two sub-basins: the Madrid sub-basin to the west and the Loranca sub-basin to the east separated by the Altomira Range. Madrid sub-basin evaporites appear both in the Paleogene (Fig. 6A) and the Neogene sequences, but most predominant in the lacustrine deposits of the Miocene's Lower and Intermediate Units (Fig. 5), where thick deposits of sulfates (mainly gypsum, glauberite and thenardite) and halite precipitated (Calvo et al., 1996). Despite the wide variety of evaporite minerals formed during this time interval, only gypsum is exposed. In the Loranca sub-basin, evaporitic sedimentation occurs from late Oligocene to Miocene ages (Arribas and Díaz-Molina, 1996; Díaz-Molina, 1974).

3.3.1.3. Ebro Basin Zone. this is one of the most prolific Cenozoic basins containing evaporites of Spain. There are nearly $4700 \mathrm{~km}^{2}$ of outcropping Paleogene and Neogene gypsum-bearing units (Table 2). Most of them are continental in origin, except for two sequences, Beuda Gypsum Formation (Fig. 6B) and the South-Pyrenees potash basin that represent two transgressive events of Lutetian and Priabonian ages with important economic resources. Continental evaporites were formed from the Eocene (Barbastro, Puente la Reina and Copons gypsum) to the upper Miocene (Cerezo gypsum, Fig. 6C) with evaporitic sedimentation taking place during all Cenozoic Epochs (Ortí, 1990).

3.3.1.4. Duero-Almazán BasinZone. in the Almazán sub-basin gypsiferous materials beds are exposed in the Bordalba-Deza area, at the top of a Paleocene sequence of marly limestones and clays (Lendinez et al., 1991b). A Middle Miocene deposit composed of sand, clay and marls with interbedded carbonates and gypsum layers appears towards the south (Lendinez et al., 1991a). Another Paleogene evaporitic unit is the Santibáñez del Val Formation, but in sedimentological studies of the area no evaporites have been described (Alonso et al, 1991; Quintero et al., 1982; Suárez-Rodríguez et al., 2008). Therefore, the Santibáñez del Val Formation is not taken into account for further calculations. In the Duero sub-basin, evaporites are located in Miocene deposits (Ramblian to Vallesian), where these are found in several units interpreted as lacustrine-palustrine systems that formed the central areas of an endorheic basin (Armenteros et al., 2002). Most of the evaporitic materials appear as gypsum facies in the northern, eastern and central parts of the Duero Basin (Villatoro and Cuestas Units), where selenite gypsum crystals are common (Fig. 6D).

3.3.1.5. Internal Betic Zone. several Neogene basins occur in this area (outer basins) and in the contact area between the Internal and the External Betic Zones (inner basins). Both areas have similar environmental evolution up to late Tortonian times (Braga et al., 2002). From this moment, the inner basins became isolated from the Mediterranean area by uplifted blocks and aridity became dominant. These climate conditions resulted in the genesis of hundreds of meters-thick evaporite sequences containing mainly gypsum. Sedimentation of evaporites in the inner basins occurred from late Tortonian to early Messinian times. Meanwhile, the outer basins remained connected to the sea, except for short periods of time, mainly during the late Messinian, when the basins were isolated from the sea (i.e. Caños Formation in the Sorbas basin). Evaporites contain primary gypsum, which appears as characteristic selenite crystals (Fig. 6E and F). In some cases halite has been described from areas such as Lorca basin (Playá et al., 2000). The Sorbas basin is the main source area for gypsum that is exported from Spain (nearly 3 million tonnes in 2009). The enormous reserves of very high quality Sorbas gypsum, together with the proximity to port facilities, make this area an important international trading centre for this commodity.

\subsubsection{Quaternary}

There are about $1092.1 \mathrm{~km}^{2}$ of Quaternary sulfate rich sediments outcropping all over Spanish territory (Fig. 5). They formed from lower Pleistocene to Holocene. In continental environments, there are currently active endorheic evaporitic areas like those of the Tajo-Mancha Basin Zone (De la Peña and Marfil, 1986; Ordóñez et al., 1994; Pueyo and de la Peña, 1981; Schreiber et al., 2001) (Fig. 7A, B and C), Duero-Almazán Basin Zone (Santisteban et al., 


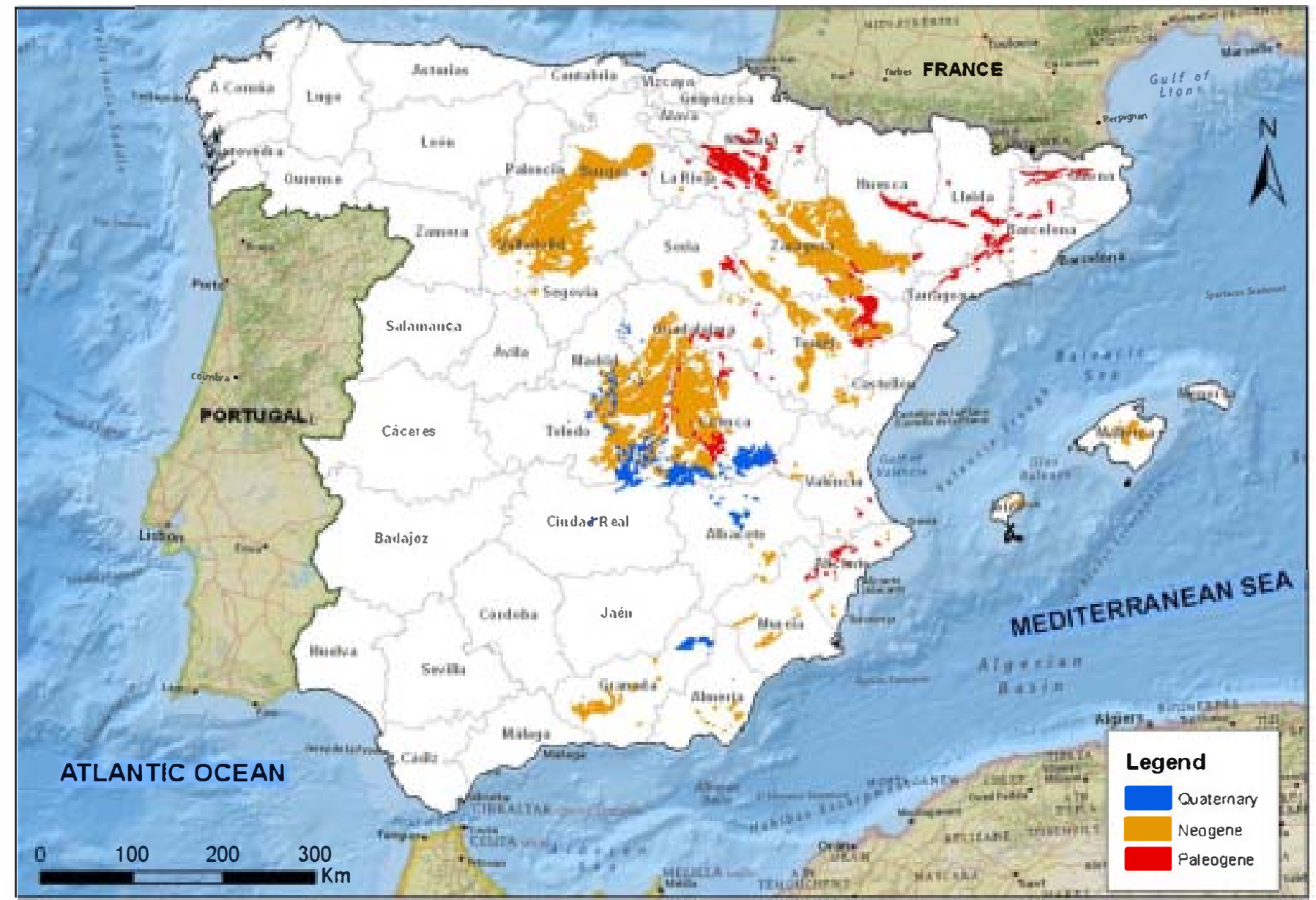

Fig. 5. Iocation of Cenozoic gypsum-bearing units outcrops in Spain.

2003), Iberian Range Zone (Pérez et al., 2002) and Ebro Basin Zone (De la Peña and Marfil, 1986; Mees et al., 2011; Mingarro et al., 1981; Pueyo, 1978/79; Pueyo and de la Peña, 1981). In these areas, playa-lakes are common with complex mineralogical associations (gypsum, epsomite, thenardite, glauberite, halite and bittern salts).

Coastal and inland salt exploitations have not been taken into account for this study even though they play an important economic and scientific role. From the total 22 million tonnes of salt produced in Spain in 2010, 19.6 million tons were exploited from coastal salinas (Fig. 7D), and 92000 tonnes from inland Salinas. The remaining 2.4 million tonnes were obtained from Barcelona and Navarra salt mines (DGPEM, 2010). In addition to their economic interest, salinas are a field laboratory to study evaporite crystallization sequences, brine chemistry evolution and early diagenetic processes in saline environments (Pueyo, 1981).

\section{Discussion}

The position of the Spanish major gypsum outcrops on geological maps enables to classify them by age and to establish their other important characteristics. Comparing these results with the main gypsum deposits in the world allows understanding the main factors that have controlled their origin.

\section{Controls on evaporitic deposition in the geological record of Spain}

The precipitation of salts as evaporites in restricted basins occurs under extreme climatic conditions, where the water loss exceeds inflow in a brine. The evaporation increases salt concentration due to progressive reaching of the saturation levels of the dissolved species (Warren, 2006). According to Warren (2006), the existence and characteristics of the evaporitic deposits are controlled primarily by three factors, tectonics, climate and chemistry of the brine, and their interactions (Fig. 8).

The chemistry of the brine, the degree of concentration (controlled by climate and tectonics) and the method of concentration (evaporation or freezing) control the primary mineralogy of the saline deposits (Rouchy and Blanc-Valleron, 2009). The chemistry of the brine is a key factor for continental and mixed marine-continental settings (Warren, 2006). In pure marine environments, the degree of concentrathon of the brine is the main factor for the initial mineralogy of the deposit. Hydrothermal and volcanic activity can provide brines and ions that would impact in the mineralogy of the deposit. Nevertheless, the final mineralogy depends on the initial mineralogy as well as the diagenetic history of the rock (Schreiber and El Tabakh, 2000).

The volume of the evaporite deposits is controlled both by tectonic activity, which produces the space to be filled, and climate, which feeds the system with extra brines. Tectonic activity can also produce low humidity areas due to riggering of topographical barriers (rain shadows beyond mountain belts) or by increasing distance to the sea (continental climate in the interior of merged supercontinents). Climate controls the water input to the system, primarily by the rainfall, which is progressively enriched in ions from pre-existing minerals. Materials arrangement and cyclical nature of the deposits can be due to climatic cycles (diurnal, seasonal, icehouse-greenhouse, etc.) that modify temperature, air humidity, precipitation, wind intensity and direction, etc. 

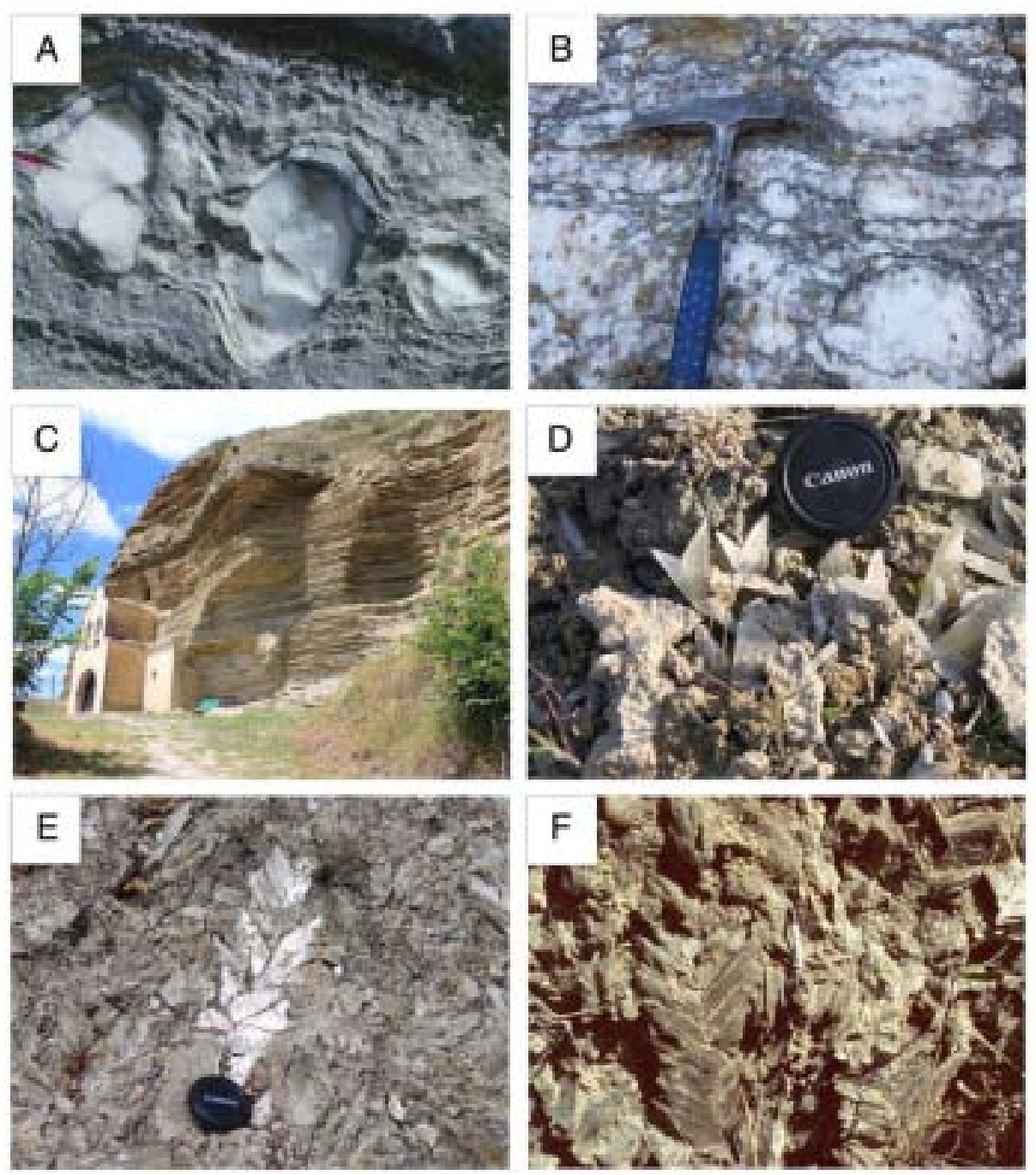

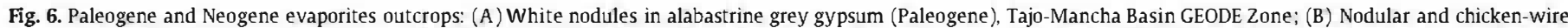

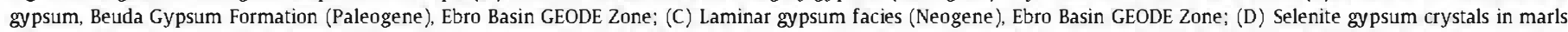

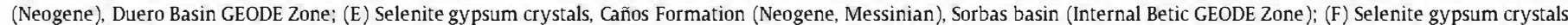
(Neogene, Messinian), San Miguel de Salinas (Internal Betic GEODE Zone).

Tectonic pulses can produce cyclic features in the deposits by successive modification of the basin geometry and the change in the materials arriving at the basin center (i.e. terrigenous materials). Plate motion impacts directly in the local climate through variation of the latitude.

There are many studies dealing with the relationship between the main evaporite depositional periods of the Earth history and the factors and their implications involved in evaporite deposition (Fig. 9).
Fischer (1982) pointed out that generation of evaporites follows an oscillation pattern in the geological record that is in phase with parameters such as magmatic activity. This author established $300 \mathrm{My}$ long cycles based on parameters such as sea level oscillations, variation in the magmatic activity and its control in climate, atmospheric $\mathrm{CO}_{2}$ levels and generation of topographic barriers. He proposed that the Earth conditions vary between greenhouse states with high

Table 2

Area $\left(\mathrm{km}^{2}\right)$ of gypsum-bearing units outcrops classified by GEODE Zone and Period. Permo-Triassic, Middle Triassic, Cretaceous and Quaternary are grouped in the column named Rest of Periods.

\begin{tabular}{|c|c|c|c|c|c|c|}
\hline Geode Zones/Period & Upper Triassic & Jurassic & Paleogene & Neogene & Rest of Periods & Total \\
\hline Cantabrian & 152.2 & 18.0 & & & & 170.2 \\
\hline Pyrenees-Vascocantabrian Ranges & 380.8 & & & & & 380.8 \\
\hline Iberian Range & 1441.5 & 1.5 & 291.7 & 1386.4 & 668.1 & 3789.2 \\
\hline Prebetic & 1466.0 & 1046.7 & 35.6 & 38.6 & 5.3 & 2592.2 \\
\hline Internal Betic & 215.5 & & & 64.7 & 241.2 & 521.4 \\
\hline Balearic Islands & 70.0 & & & 129.5 & & 199.5 \\
\hline Duero-Almazan Basin & & & 40.8 & 1991.7 & 0.1 & 2032.6 \\
\hline Tajo-Mancha Basin & 3.9 & & 401.3 & 4283.6 & 1052.6 & 5741.3 \\
\hline Guadalquivir Basin + Subbetic & 99.5 & & & 249.1 & 122.8 & 471.4 \\
\hline Ebro Basin & & 1.8 & 1438.8 & 3235.0 & 9.8 & 4685.3 \\
\hline Valencia Subsiding Basin & 114.9 & & & 6.1 & 3.9 & 124.8 \\
\hline Catalonia (only Mesozoic) & 253.0 & & & & 115.4 & 368.4 \\
\hline Total & 4197.3 & 1068.0 & 2208.1 & $11,384.6$ & 2219.1 & $21,077.1$ \\
\hline
\end{tabular}



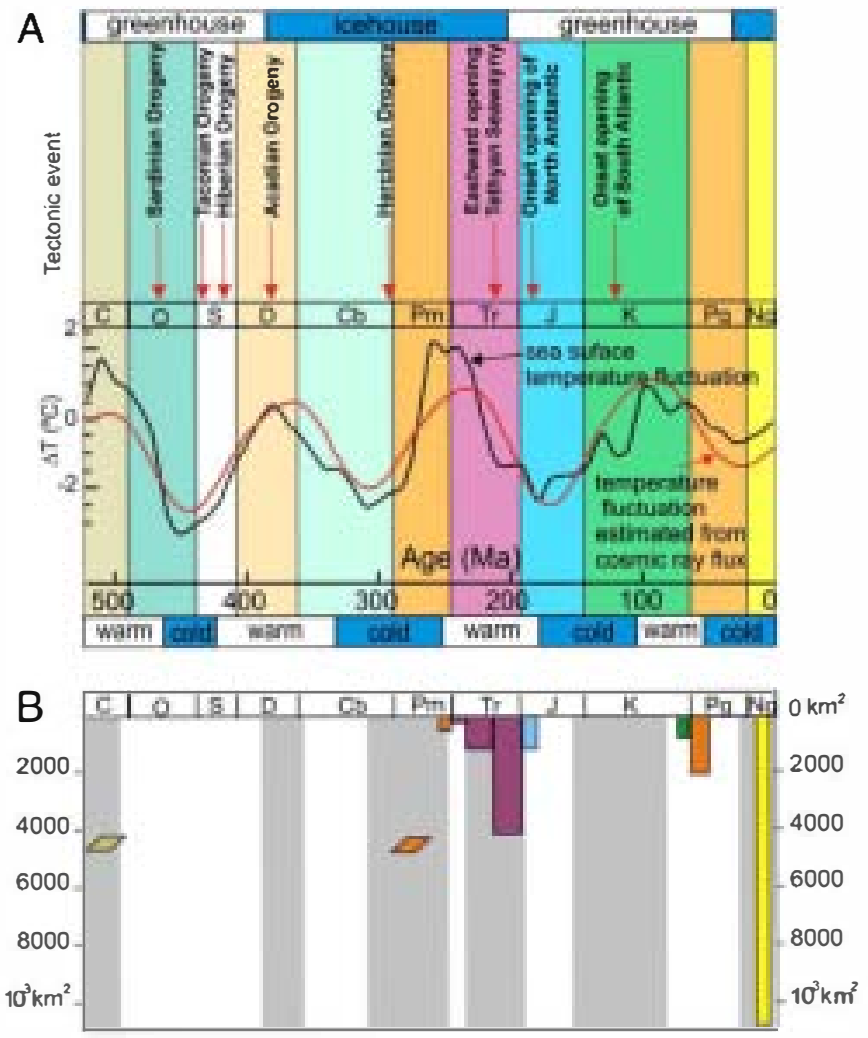

Fig. 9. (A) Long oscillation cycles observed in the sedimentary record and their proposed interpretations (greenhouse after Fischer (1982); tectonics after Warren (2010); warm-cold cycles and temperature curves of the sea surface after Shaviv and Veizer (2003) and Veizer et al. (2000); (B) Surface of Spanish gypsum outcrops for different ages (USGS, 2009) with the vertical scale in $\mathrm{km}^{2}$ of outcrop. In grey are marked the global moments of massive evaporite sedimentation (Warren, 2010). Rhombohedra mark the occurrence in Spain of evaporitic mouldic porosity or pseudomorphs after evaporite minerals.

stated earlier, their age is controversial. They appear to be overlying rocks affected by the Hercynian Orogeny (Fig. 9). Permian deposits are found in a wide variety of basins in northern and central Europe (i.e. the Zechstein basin) and represent deserts formed in the interior of the Hercynian foreland basin, related to the final accretion of the Pangea supercontinent. The Zechstein late Pemian salts were deposited when the sea was subjected to subsea-level depressions (Warren, 2010). The Permian salt deposits were formed when the sea surface reached the highest recorded temperature of the Earth (Veizer et al., 2000).

Triassic evaporite deposits are widely exposed in many areas of the north (Cantabria and Basque provinces), east (Pyrenees and Iberian Ranges), and south (Betic Cordilleras). The Triassic evaporite sedimentation is related to the initial opening of the Atlantic Ocean (Fig. 9) and the evaporite salts were formed at the interior of the Pangea supercontinent, close to an arid Horse Latitude (Warren, 2010). They were forned all through the Triassic, showing a volume increase towards the top of the period. This time span has been characterized as a warn cycle (Fischer, 1982), where the temperature of the water surface was decreasing with time. The precipitation of evaporites took place during the lower sea level parts of various transgressive-regressive cycles.

Due to their plastic character, the Triassic facies have acted as decollement surf aces mainly during the tectonic movements associated with the Alpine Orogeny. This is observed in the outcrop distribution that limits the main Alpine tectonic features.

Jurassic evaporites appear as small outcrops in the Cantabrian and Iberian Range Zones. The biggest concentration of evaporites occurs in the Prebetic Range (south-east Spain). The sea surface temperatures were relatively low during the Jurassic period. There was an increase in the temperature trend during the Cretaceous, with several minor cycles. The Cretaceous evaporites in Spain appear in the Duero basin margins, Iberian Range and towards Eastem Spain. During the Aptian period, rifting of the south-Atlantic produced the compartmentalization of different grabens and sub-grabens that were filled by detrital sediments derived from the rift borders. Towards the Barremian, the tectonic activity was drastically reduced, and lacustrine environments dominated the sedimentation of these basins. The Jurassic and Cretaceous periods record declining salinity conditions, associated with salt extractions during the opening of North-Atlantic (Middle to Upper Jurassic) and South-Atlantic (Lower Cretaceous) (Fig. 9). During the post-rift depositional phases (Warren, 2010) sedimentation was characterized by frequent sea level variations (Hallam, 1977; Vail et al., 1977), with deposition of evaporites that altemate with marine shelf and platform carbonates.

Cenozoic salt deposits are located in saline units of the Ebro, Duero and Tajo basins. There are also some saline formations in intramontane and marginal basins of the Betic Cordillera in southern Spain.

Paleogene deposits are abundant in the north-eastern part of Spain. Most of the outcropping gypsum is of continental origin (Iberian Range and west of the Ebro basin). However, those located at the eastern part of the Ebro basin appear to be related to the last two marine incursions (Priabonian and Lutetian ages) of the Atlantic.

In the Neogene, the evaporite deposits crop out in the central parts of the endorheic Duero, Ebro and Tajo basins, with variable lateral extent and vertical thicknesses. Small Neogene intramontane basins (Iberian and Catalonian Coastal Ranges and Betic Cordillera) formed by the subdivision of the Tethys into many smaller size basins. These continental evaporites were originated from brines formed by the dissolution of previous evaporite deposits, mostly Triassic and sometimes Permian. The evaporite deposits formed the central part of continental lacustrine deposits.

There are also various marine gypsum deposits of Neogene age in southern Spain. These are located at the margins of the latest saline giant deposits that filled several Messinian basins of the Mediterranean region. The Messinian basins system was created during the collision of Eurasia with North Africa, just af ter the onset of the ice cap of Antarctica. The salts precipitation was due to evaporation of great volumes of seawater that seeped into the hydrographically restricted sub-sea level depressions of the Mediterranean basin.

Quatemary deposits appear in the Tajo, Duero and Ebro basins and in coastal and inland salinas. The continental evaporites form in endorheic lacus rine settings that are feed by waters that leach older evaporite deposits (Warren, 2006). In Spain, most of the inland salinas have concentrated brines due to chemicals sourced from Triassic terrains.

The diverse sedimentary settings of evaporite deposits appear in the Spanish geological record reflect the complex processes operating in the evaporite deposition.

Spanish evaporitic sedimentation from late Permian to early Jurassic took place in a system where global geologic factors controlled the salts deposition. The time of formation of the Spanish deposits correlates perfectly with a global warming period and the deposition of saline bodies in other parts of the World (Warren, 2010) like in the Mandawa basin, Tanzania (Warren, 2006). Most of those deposits are marine in origin and they have a strong global climatic control (Fig. 9).

Younger evaporites precipitation in Spain was governed by local or regional factors: Upper Cretaceous-Paleogene deposits and Neogene ones were deposited in intramontane basins produced by the Alpine Orogeny. This orogeny compartmentalized the Spanish territory creating topographic barriers and endorheic areas that evolved independently. These local geographic conditions explain the unexpected appearance of evaporites during unfavorable global climatic conditions 
for generation of evaporites (Fig. 9). Marine Messinian salts precipitated due to the partial closure of the Mediterranean Sea during the Alpine Orogeny.

\section{Conclusions}

The distribution pattern of Spanish gypsum outcrops indicates paleogeographical, paleoenvironmental and tectonic conditions throughout the geological history of the Iberian Peninsula.

The saline outcrops in Spain occupy $4.2 \%$ of the country's surface area. Most of the outcrops have gypsum as sole mineralogy. Other evaporite minerals such as anhydrite, halite, potassium salts, and calcium and sodium sulfates appear in the subsurface.

Evaporite outcrops are more abundant in the eastern half of the country and they are missing in most of the westem regions. Mesozoic evaporites are widely exposed in the eastern half of the country. In contrast, Cenozoic outcrops appear mainly in the northern part.

Although it can be inferred that there are evaporitic deposits in Spain as old as lower Cambrian, confirmed evaporite deposits appear from Triassic to Quaternary ages. The most abundant outcropping evaporites are Neogene in age, but most of the total volume of saline materials was deposited during the Mesozoic, mainly during the Triassic.

Marine evaporites in the Spanish geological record appear mainly in Permian, Triassic, Jurassic, Cretaceous and Neogene sequences. Salts deposits of continental origin are frequent in the Neogene, and become dominant in the Quaternary.

Mesozoic evaporitic units contributed solutes to continental drainage inflows in several endorheic depressions.

Global climate and a favorable tectonic setting are the main factors that have controlled the origin, distribution and volume of Mesozoic saline deposits of Spain. During this period, Spanish evaporite deposits were marine and their formation was controlled by global environmental and climatic conditions.

Local (continental evaporites) and regional factors (Messinian sequences) have controlled Cenozoic evaporites precipitation in Spain. The Alpine Orogeny has played a key role, generating vast endorheic basins, like the Ebro, Duero and Tajo basins, surrounded by important orographic barriers that offered the required conditions to accumulate thick deposits of continental evaporites. The collision of the African plate with the Iberian Peninsula produced the partial closure of the Mediterranean Sea and the origin of massive evaporite sequences in the Mediterranean basin. Several sub-basins produced by this tectonic event exist in or close to the Spanish Mediterranean coast with thick deposits of gypsum.

\section{Acknowledgements}

We are grateful to Professor José Andrés de la Peña for all the assistance, comments and support from the beginning of this research. $\mathrm{He}$ should be considered an author of this work. We thank the Spanish Geological Survey (IGME) for all the data freely available from its website. Thanks to two anonymous reviewers for their comments and helpful suggestions. This study was financed by the Fundación General de la Universidad Complutense de Madrid (Project 396/2009-4153239).

\section{References}

Adell, F., Bascones, F., Martínez-Alvares, L., Tena-Dávila, F., González, E. and Rodríguez Gonzalez, A., 1981. Hoja geológica num. 461 (Sigüenza). Mapa Geológico de España E. 1:50.000. Segunda serie. I.G.M.E., Madrid.

Alberto, F., Navas, A., 1986. La participación de los yesos en la salinización de las aguas superficiales de la cuenca del Ebro. I Cartografía de síntesis de las formaciones con yesos. An. Aula Dei $18(1-2), 7-18$

Aldaya, F., Puga, E., Díaz de Federico, A. and García, V., 1979. Hoja geológica num. 1042 (Lanjarón). Mapa Geológico de España E. 1:50.000. Segunda serie. I.G.M.E., Madrid

Alonso, A., Meléndez, N., Mas, R., 1991. Sedimentación lacustre durante el Cretácico en la Cordillera Ibérica, España. Acta Geol. Hisp. 26 (1), 35-54.
Álvaro, J.J., Rouchy, J.M., Bechstädt, T., Boucot, A., Boyer, F., Debrenne, F., Moreno-Eiris, E., Perejón, A., Vennin, E., 2000. Evaporitic constraints on the southward drifting of the western Gondwana margin during Early Cambrian times. Palaeogeogr Palaeoclimatol. Palaeoecol. 160 (1-2), 105-122.

Alvaro-Iópez, M., García Argüeso, J.M., Manjón, M., Navidad, M., Cabañas, I., Uvalde, M.A., Sanchez, V., Yébenes, A. and Peláez, J.R., 1977. Hoja geológica num. 814 (Villanueva de la Fuente). Mapa Geológico de España E. 1:50.000. Segunda serie. I.G.M.E., Madrid

Anadón, P., Ortí, F., Rosell, L., 1997. Unidades evaporíticas de la zona de Libros-Cascante (Mioceno, Cuenca de Teruel): características estratigráficas y sedimentológicas. Cuad. Geol. Iber. 22, 283-304.

Arias, C., Bascones, L., Lendínez, A., Martín-Herrero, D., Tena-Dávila, M. and La Moneda, E., 1981. Hoja geológica 791 (Chinchilla de Monte Aragón). Mapa Geológico de España E. 1:50.000. Segunda serie. I.G.M.E., Madrid.

Armenteros, I., Corrochano, A., Alonso-Gavilán, G., Carballeira, J., Rodríguez, J.M., 2002. Duero basin (northern Spain). Tertiary. In: Gibbons, W., Moreno, T. (Eds.), The Geology of Spain. The Geological Society, London, pp. 255-292.

Arribas, J., 1986a. Sedimentología y Diagénesis del Buntsandstein y Muschelkalk de la Rama Aragonesa de la Cordillera Ibérica (Provincias de Soria y Zaragoza). Universidad Complutense de Madrid, Madrid. $621 \mathrm{pp}$.

Arribas, M.E., 1986b. Petrología y análisis secuencial de los carbonatos lacustres del Paleógeno del sector N de la cuenca terciaria del Ta jo (provincia de Guadalajara). Cuad. Geol. Iber. 10, 295-334.

Arribas, J., Díaz-Molina, M., 1996. Saline deposits associated with fluvial fans, Iate Oligocene-Early Miocene, Loranca Basin, Central Spain. In: Friend, P., Dabrio, C (Eds.), Tertiary basins of Spain. Cambridge University Press, Cambridge, The strat igraphic record of crustal kinematics, pp. 308-312.

Aurell, M., et al., 2002.Jurassic. In: Gibbons, W., Moreno, T. (Eds.), The Geology of Spain The Geological Society, Iondon, pp. 213-253.

Bartrina, T., Hernández, E., 1990. Las unidades evaporíticas del Triásico del subsuelo del Maestrazgo. In: Orti, F., Salvany, J.(Eds.), Formaciones evaporíticas de la Cuenca del Ebro y cadenas periféricas, y de la zona de Levante. Nuevas aportaciones y guía de superficie, Enresa, Barcelona, pp. 34-38.

Benzaquen, M., Núñez, A. and Martínez, W., 1973. Hoja geológica num. 446 (Valls) Mapa Geológico de España E. 1:50.000. Segunda serie. I.G.M.E., Madrid.

Braga, J.C., Martín, J.M., Aguirre, J., 2002. Southern Spain. Tertiary. In: Gibbons, W., Moreno, T. (Eds.), The Geology of Spain. The Geological Society, Iondon, pp. 320-327.

Calvo, J.P., Alonso-Zarza, A.M., García del Cura, M.d.l.A., Ordóñez, S., Rodríguez-Aranda, J.P., Sanz-Montero, M.E., 1996. Sedimentary evolution of lake systems through the Miocene of the Madrid Basin: paleoclimatic and paleohydrological constraints. In: Friend, P., Dabrio, C. (Eds.), Tertiary basins of Spain. The stratigraphic record of crustal linematics. Cambridge University Press, Cambridge, pp. 272-277.

De la Peña, J.A., Marfil, R., 1986. Ia sedimentación salina actual en las lagunas de la Mancha: una síntesis. Cuad. Geol. Iber. 10, 235-270.

Del Olmo, P., Olivé, A., Gutiérrez, M., Aguilar, M.J., Leal, M.C. and Portero, J.M., 1983. Hoja geológica num. 438 (Paniza). Mapa Geológico de España E. 1:50.000. Segunda Serie. I.G.M.E., Madrid.

DGPEM, 2010. Estadística Minera de España. Ministerio de Industria, Energía y Turismo, Madrid, pp. 28-36.

Díaz-Molina, M., 1974. Sintesis estratigráfica preliminar de la serie terciaria de los alrededores de Carrascosa del Campo. Estud. Geol. 35, 241-251.

Egeler, C.G., Kampschuur, W., Iangenberg, C.W., Montenat, C, Pignatelli, R. and Rondeel, H.E., 1974. Hoja geológica 954 (Totana). Mapa Geológico de España E. 1:50.000. Segunda Serie. IGME, Madrid.

Elizaga, E., Gállego, I.C., García de Domingo, A. and López, F., 1984. Hoja geológica 843 (Hellín). Mapa Geológico de España E. 1:50.000. Segunda serie. I.G.M.E., Madrid.

Escavy, J.I., Herrero, M.J., Bustillo, M., 2011. Spanish gypsum market: is life af ter death? In: IAS (Ed.), 28th IAS Meeting of Sedimentology, Zaragoza (Spain).

Espinosa, J.M., Martín-Vivaldi, J.M., Martín-Alafont, J.M. and Pereda, M., 1974a. Hoja geológica 997 (Aguilas). Mapa Geológico de España E. 1:50.000. Segunda Serie. I.G.M.E., Madrid

Espinosa,J.M., Martín-Vivaldi,J.M., Martín-Alafont,J.M., Pereda, M., Perez, A. and López, M.J., 1974b. Hoja geológica 976 (Mazarrón). Mapa Geológico de España E 1:50.000. Segunda Serie. I.G.M.E., Madrid.

Fernández-Calvo, C, 1981. Sedimentología y Diagénesis del Cretácico Superior de la Mancha (Provinciade Cuenca). Universidad Complutense de Madrid Madrid. $297 \mathrm{pp}$

Fischer, A.G., 1982. Iong-term climatic oscillations recorded in stratigraphy. In: Berger, W.H., Crowell, J.C. (Eds.), Climate in Earth History. National Academy of Sciences, Studies in Geophysics, Washington, D.C, pp. 97-104

García-Mondejar, J., Pujalte, V., Robles, S., 1986. Características Sedimentológicas, Secuenciales y Tectoestratigráficas del Triásico de Cantabria y Norte de Palencia. Cuad. Geol. Iber. 10, 151-172.

García-Velez, A. and Soubrier, J., 1981. Hoja geológica 795 (Játiva). Mapa Geológico de España E. 1:50.000. Segunda serie. I.G.M.E., Madrid.

García-Vélez, A., García-Ruz, L., Muelas, A., Soubrier, J. and Forcat, C., 1981. Hojageológica 746 (Llombay). Mapa Geológico de España E. 1:50.000. Segunda serie. I.G.M.E., Madrid.

Garrido-Megías, A., Villena, J., 1977. El Trias Germánico en España: Paleogeografia y Estudio Secuencial. Cuad. Geol. Iber. 4, 37-56.

Gervilla, M., Beroiz, C. Pignatelli, R., Baron, A., Coma, JE, Feloueroso, C, Ramirez del Pozo, J. and Giannini, G., 1973. Hoja geológica 29 (Oviedo). Mapa Geológico de España E. 1:50.000. Segunda Serie. I.G.M.E., Madrid

Gil A., Fernández, J., García-Hernández, M., Hirsch, F., 1987. Las Facies Carbonatadas del Trías Medio de la Formación Hornos-Siles (Provincia de Jaén, Zona Prebética) Cuad. Geol. Iber. 11, 445-458.

Gómez, J.J., Goy, A., 1998. Las unidades litoestratigráficas del tránsito Triásico-Jurásico en la región de Lécera (Zaragoza). Geogaceta 23, 63-66. 
Gutiérrez, F., Calaforra, J.M., Cardona, F., Ortí, F., Durán, J.J., Garay, P., 2008. Geológical and environmental implications of the evaporite karst in Spain. Environ. GeoL (53), 951-965.

Hallam, A., 1977. Secular changes in marine inundation of USSR and North America through the Phanerozoic. Nature 269, 769-772.

Hardie, L.A., 1996. Secular variations in seawater chemistry: an explanation for the coupled secular variation in the mineralogies of marine limestones and potash evaporites overt the past 600 My. Geology 24, 279-283.

IGME, 2012. www.igme.es.

Julivert, M., Truyols, J., Ramirez del Pozo, J. and Giannini, G., 1973. Hoja geológica 14 (Gijón). Mapa Geológico de España E. 1:50.000. Segunda Serie. LG.M.E., Madrid.

Iaya, H., Benayas, J., Marfil, R., 1993. Yesos lenticulares de orígen detrítico en suelo de la España central. Cuaternario y Geomorfología 7, 49-56.

Iendínez, A., Gabaldón, V. and Martín, A., 1991a. Hoja geológica 435 (Arcos de Jalón) Mapa Geológico de España E. 1:50.000. Segunda serie. LG.M.E., Madrid.

Iendínez, A., Ruiz Fernández de la Lopa, V., Gabaldón, V. and Serrano, A., 1991b. Hoja geológica 408 (Torrijo de la Cañada). Mapa Geológico de España E. 1:50.000. Segunda serie. LG.M.E., Madrid.

López-Garrido, A.C., González Donoso, J.M., Linares, A. and García Hernández, M., 1975. Hojageológica 887 (Orcera). Mapa Geológico de España E. 1:50.000. Segunda Serie. LG.M.E., Madrid.

López-Gómez, J., Arche, A., Pérez-López, A., 2002. Permian and Triassic. In: Gibbons, W., Moreno, T. (Eds.), The Geology of Spain. The Geological Society, Iondon, pp. 185-212.

Marfil, R., 1970. Estudio Petrogenétioo del Keuper en el sector meridional de la Cordillera Ibérica. Estud. GeoL XXVI (2), 113-161.

Marfil, R., Arribas, J., Arribas, M.E., de la Peña, J.A, 1984. Sedimentación lacustre (Carbonatado-Salina) en la facies Autuniense de la Cordillera Ibérica. In: Obrador, A. (Ed.), Publicaciones de Geología, no 20. Homenaje a Luís Sánchez de la Torre. Grupo Español de Sedimentología. Universidad de Barcelona, Barcelona.

Martín, M., Canerot, J. and Leyva, F., 1979. Hoja geológica 517 (Argente). Mapa Geológico de España E. 1:50.000. Segunda Serie. LG.M.E., Madrid.

Martín-Chivelet, J., 1994. Litoestratigrafía del Cretácico superior del Altiplano de Jumilla-Yecla (Zona Prebética). Cuad. Geol Iber. 18, 117-173.

Martín-Chivelet, J., et aI., 2002. Cretaceous. In: Gibbons, W., Moreno, T. (Eds.), The Geology of Spain. The Geological Society, London, pp. 255-292.

Martínez-García, E., Coquel, R., Gutiérrez-Claverol, M., Quiroga, J.L., 1998. Edad del "Tramo de transición" entre el Pérmico y elJurásico en el área de Gijón (Asturias, NW de España). Geogaceta 24, 215-218

Mees, F., Castañeda, C., Herrero, J., Van Ramst, E., 2011. Bloedite sedimentation in a seasonally dry saline lake (Salada Mediana, Spain). Sed. GeoL 238, 106-115.

Mingarro, F., Ordóñez, S., López de Azcona, M.C., García del Cura, M.A., 1981 Sedimentoquímica de las lagunas de Los Monegros y su entorno geológico. BoL GeoL Min. 92, 171-195.

Morad, S., Al-A49SM, I.S., Longstaffe, F.J., Marfil, R., De Ros, L.F., Johansen, H., Marzo, M., 1995. Diagenesis of a mixed siliciclastic/evaporitic sequence of the Middle Muschelkalk (Middle Triassic), the Catalan Coastal Range, NE Spain. Sedimentology 42, 749-768.

Ordóñez, S., Sánchez-Moral, S., García del Cura, M.A. Rodríguez Badiola, E., 1994. Precipitation of salts from $\mathrm{Mg}^{2+}-\mathrm{Na}^{+}-\mathrm{SO}^{2-}-\mathrm{Cl}^{-}$playa lake brines: the endorheic saline ponds of Ia Mancha, central Spain. In: Renaut, R.W., Iast, W.M. (Eds.), Sedimentology and Geochimistry of Modern and Ancient Saline Lakes. SEPM Special Publication, SEPM, pp. 61-71

Ortí, F., 1974. El Keuper del Levante español Estudios Geológicos, XXX . 7-46.

Ortí, F., 1987. Aspectos sedimentológicos de las evaporitas del Triásico y Liásico inferior en el Este de la Península Ibérica. Cuad. GeoL Iber. 11, 837-858.

Ortí, F., 1990. Introducción a las evaporitas de la Cuenca Terciaria del Ebro. In: Orti, F. Salvany, J. (Eds.), Formaciones evaporíticas de la Cuenca del Ebro y cadenas periféricas, y de la zona de Levante. Nuevas aportaciones y guía de superficie, Enresa, Barcelona, pp. 62-66.

Ortí, F., Rosell, L., 2000. Evaporative systems and diagenetic patterns in the Calatayud Basin (Miocene, central Spain). Sedimentology 47, 665-685.

Ortí, F., García-Veigas, J., Rosell Ortiz, L., Jurado, M.J., Utrilla, R., 1996. Formaciones salinas de las cuencas triásicas en la Península Ibérica: caracterización petrológica y geoquímica. Cuad. Geol Iber. 20, 13-35.

Pérez, A., Luzón, A., Roc, A.C., Soria, A.R., Mayayo, M.J., Sánchez, J.A., 2002. Sedimentary facies distribution and genesis of a recent carbonate-rich saline lake: Gallocanta Lake, Iberian Chain, NE Spain. Sed. GeoL 148, 185-202.

Playá, E., Ortí, F., Rosell, L., 2000. Marine to non-marine sedimentation in the upper Miocene evaporites of the Eastern Betics, SE Spain: sedimentological and geochemical evidence. Sed. Geol 133, 135-166.

Porta, J., López-Acevedo, M., Roquero de Laburu, C., 2003. Edafología para la agricultura y el medio ambiente. Ediciones Mundi-Prensa, Madrid. (960 pp.).

Portero, J.M., Aznar, J.M., Díaz-Molina, M., Pérez-González, A., Gallardo, J., GonzálezLodeiro, F., Aguilar, M.J. and Leal, M.C., 1990. Hoja geológica 486 (Jadraque). Mapa Geológico de España E. 1:50.000. Segunda serie. LG.M.E., Madrid.

Pueyo, J.J., 1978/79. La precipitación evaporítica actual en las lagunas saladas del área: Bujaraloz, Sástago, Caspe, Alcañiz y Calanda. Rev. Inst. Invest. Geológicas 33, 5-56.

Pueyo, J.J., 1981. Depósitos evaporíticos actuales dellitoral mediterráneo de la Península Ibérica. In: Pueyo, J.J. (Ed.), Génesis de las formaciones evaporíticas. Modelos andinos e ibérioos. Publicaciones de la Universidad de Barcelona, Barcelona, pp. 135-147.
Pueyo, J.J., de la Peña, J.A, 1981. Los lagos salinos españoles. Sedimentología hidroquímica y diagénesis. In: Pueyo, J.J. (Ed.), Génesis de las formaciones evaporíticas. Modelos andinos e ibéricos. Publicaciones de la Universidad de Barcelona, Barcelona, pp. 163-192.

Puga, E., Nieto, J.M., Díaz de Federico, A., Portugal, E., Reyes, E., 1996. The intra-orogenic Soportújar Formation of the Mulhacen Complex; evidence for the polyciclic character of the Alpine orogeny in the Betic Cordilleras. Eclogae Geol Helv. 89, 129-162

Quintero, I., Mansilla, H. and Martínez-Díaz, C., 1982. Hoja geológica 315 (Santo Domingo de Silos). Mapa Geológico de España E. 1:50.000. Segunda serie. LG.M.E., Madrid.

Ramos, A., 1979. Estratigrafíay paleogeografía del Pérmico y Triásico al oeste de Molina de Aragón (Provincia de Guadalajara). Universidad Complutense de Madrid, Madrid. (313 pp.).

Regueiro, M., Calvo, J.P., 1997. El yeso. Geología yyacimientos en España. BoL Soc. Esp. Ceram. V 36 (6), 563-569

Riba, O., Macau, F., 1962. Situación, Características y Extensión de los Terrenos Yesíferos en España. I Coloquio Internacional Sobre las Obras Públicas en los Terrenos Yesíferos Servicio Geológico de Obras Públicas. Ministerio de Obras Públicas, Madrid. (33 pp.).

Robles, S., Pujalte, V., 2004. El Triásico de la Cordillera Cantábrica. In: Vera, J.A. (Ed.) Geología de España. SGE-IGME, Madrid, pp. 274-276.

Rodríguez-López, J.P., Meléndez, N., De Boer, P., Soria, A.R., 2012. Controls on marineerg margin cycle variability: aeolian-marine interaction in the mid-Cretaceous Iberian Desert System, Spain. Sedimentology 59, 466-501.

Rodríguez-Perea, A., Ramos-Guerrero, E., Pomar, L., Paniello, X., Obrador, A., Martí, J., 1987. El Triásico de las Baleares. Cuad. GeoL Iber. 11, 295-321.

Rouchy, J.M., Blanc-Valleron, M.M., 2009. Les évaporites: materiaux singuliers, millieux extrèmes. Vuibert, Société géologique de France, Paris.

Royer, D.L., Berner, R.A., Montanez, LP., Tabor, N.J., Beerling, D.J., 2004. $\mathrm{CO}_{2}$ as a primary rdiver of Phanerozoic climate. GSA Today 14,4-10.

Salazar, K., McNutt, M.K., 2011. Mineral Commodity Summaries 2011. U.S. Department of the Interior, Reston.

Salvany, J., 1990. Introducción a las evaporítas triásicas de las cadenas periféricas de la cuenca del Ebro: Catalanides, Pirineo y Región Cantábrica. In: Orti, F., Salvany, J. (Eds.), Formaciones evaporíticas de la Cuenca del Ebro y cadenas periféricas, y de la zona de Levante. Nuevas aportaciones y guía de superficie, Enresa, Barcelona, pp. $9-20$.

Salvany, J., Ortí, F., 1987. El Keuper de los Catalánides. Cuad. GeoL Iber. 11, 215-236.

Santisteban, J.L, García del Cura, M.A., Mediavilla, R., Dabrio, C., 2003. Estudio preliminar de los sedimentos recientes de las lagunas de Villafáfila. Geogaceta $33,51-54$.

Sanz, D., 2009. Análisis del yeso empleado en revestimientos exteriores mediante técnicas geológicas. Universidad Politécnica de Madrid, Madrid. (314 pp.).

Schreiber, B.C., El Tabakh, M., 2000. Deposition and early alteration of evaporites. Sedimentology 47, 215-238.

Schreiber, B.C., Philp, R.P., Benali, S., Helman, M.L., De la Peña, J.A., Marfil, R., Landais, P., Cohen, A.D., Kendall, C.G.S.C., 2001. Characterisation of organic matter formed in hypersaline carbonate/evaporite environments: hydrocarbon potential and biomarkers obtained through artificial maturation studies. J. Pet. GeoL 24 (3), 309-338

Shaviv, N.J., Veizer, J., 2003. Celestial driver of Phanerozoic climate? GSA Today 13 , $4-10$

Sopeña, A., 1979. Estratigrafia del Pérmico y Triásico del Noroeste de la Provincia de Guadala jara. Universidad Complutense de Madrid, Madrid. (329 pp.).

Stanley, S.M., Hardie, L.A., 1998. Secular oscillations in the carbonate mineralogy of reef-building and sediment-producing organisms driven by tectonically forced shifts in seawater chemistry. Palaeogeogr. Palaeoclimatol PalaeoecoL 144, 3-19.

Suárez-Rodríguez, A., García-Espina, R., Armenteros, I., Barba, P., Herrero, A., Galán, L.A and Baltuille, J.M., 2008. Hoja geológica 347 (Peñaranda de Duero). Mapa Geológico de España E. 1:50.000. Segunda serie. LG.M.E., Madrid.

USGS, 2009. International Stratigraphic Chart. In: LC.o. Stratigraphy (Ed.).

Vail, P.R, Mitchum, R.M., Todd, R.G., Widmier, J.M., Thompson, S., Sangree, J.B., Bubb, J.N., Hatleud, W.G., 1977. Seismic stratigraphy and global changes of the sea level. In: Payton, C.E. (Ed.), Seismic stratigraphy - Applications to Hydrocarbon Exploration. Geologists Memoirs, American Association of Petroleum Geologists, pp. 49-212

Veizer, J., Godderis, Y., Francois, L.M., 2000. Evidence for decoupling of atmosferic $\mathrm{CO}_{2}$ and global climate during the Phanerozoic eon. Nature 408, 698-701.

Vera, J.A., Vilas, L., Ruiz-Ortiz, P., Martín-Chivelet, J., Arias, C., Molina, J.M., Castro, J.M., Chacón, B., García-Hernández, M., 2002. Betics (Cretaceous). In: Gibbons, W., Moreno, T. (Eds.), The Geology of Spain. The Geological Society, London, pp. 255-292.

Virgili, C., 1955. El tramo rojo intermedio del Muschelkalk de los Catalánides. Memorias y Comunicaciones del Instituto Geológico Provincial. Barcelona, XIII. 37-78.

Virgili, C., 1958. El Triásico de los Catalánides. Boletín Geológico y Minero, LXIX. 1-856

Warren, J., 2006. Evaporites: sediments, resources and hydrocarbons. Springer, Berlin . (1035 pp.).

Warren, J., 2010. Evaporites through Time: Tectonic, climatic and eustatic controls in marine and nonmarine deposits. Earth Science Reviews, 98. Elsevier. (124 pp.). 